\title{
Persistent hypoxaemia after a pneumonia: a rare cause to consider
}

\author{
Maria Filomena Cardosa 다, ${ }^{1}$ Odete Mingas 지, ${ }^{2}$ Rita Ramos, ${ }^{1}$ Ana R Araújo
}

${ }^{1}$ Department of Pediatrics, Hospital Garcia de Orta EPE, Almada, Portugal ${ }^{2}$ Department of Pediatric Cardiology, Hospital de Santa Cruz, Centro Hospitalar de Lisboa Ocidental, Lisboa, Portugal

\section{Correspondence to} Dr Maria Filomena Cardosa; filomena.cardosa@gmail.com

Accepted 7 April 2021
Check for updates

(c) BMJ Publishing Group Limited 2021. No commercial re-use. See rights and permissions. Published by BMJ.

\begin{tabular}{|l|}
\hline To cite: Cardosa MF, \\
Mingas O, Ramos R, \\
et al. BMJ Case Rep \\
2021;14:e241491. \\
doi:10.1136/bcr-2020- \\
241491 \\
\hline
\end{tabular}

\section{DESCRIPTION}

We describe the case of a previously healthy 9-year-old girl hospitalised due to hypoxaemic pneumonia. Two months after discharge, she maintained low oxygen saturations and persistent dry cough without dyspnoea, haemoptysis, migraine or palpitations. Cardiac and pulmonary auscultation was normal, and cyanosis or clubbing were not present. There was no personal or family history of mucocutaneous bleeding or telangiectasias. Thoracic radiography showed peribronchovascular thickening (figure 1). Due to persistence of symptoms, computed chest tomography (CCT) was performed and revealed pulmonary arteriovenous malformation (PAVM). Conventional angiography confirmed a large PAVM $(23 \times 19 \mathrm{~mm})$ on the right parahilar topography with afferent artery draining into the right upper pulmonary vein and efferent vessel draining into the left atrium (figure 2). Percutaneous closure was performed with implantation of an Amplatzer-Duct-Occluder-I device (5/4). Clinical follow-up showed regression of hypoxaemia and she remained asymptomatic without recurrence.

PAVMs are structurally abnormal vascular communications that provide continuous right-toleft shunt between pulmonary arteries and veins. Limited prevalence data suggest that PAVMs may affect 1 out of 2600 individuals, being 1.5-2 times more frequent among women. ${ }^{1}$ Most PAVMs are congenital and due to hereditary haemorrhagic telangiectasia (HHT) but can occur in a variety of acquired medical conditions: hepatic cirrhosis, penetrating chest trauma, mitral stenosis, Fanconi syndrome, schistosomiasis, actinomycosis and metastatic thyroid carcinoma. ${ }^{2-8}$ PAVMs can also develop as a complication after congenital heart surgery. ${ }^{9} 10$ PAVMs are classified as simple or complex. Simple PAVMs are the most frequent (80\%-95\%) and are characteristically perfused by arteries arising from a single subsegmental artery. ${ }^{11} 12$ Complex PAVMs are perfused by more than one subsegmental artery and are typically telangiectases. ${ }^{13}$ In about $95 \%$ of cases, PAVMs are supplied by pulmonary arteries draining in pulmonary veins. Rarely they are fed by systemic arteries and/or drain into the left atrium or inferior vena cava, as we observed in our case. About $60 \%$ of cases are asymptomatic, incidentally found on chest imaging or during HHT screening. ${ }^{14-19}$ Most common symptoms are dyspnoea (13\%-56\%) and haemoptysis (7\%-30\%). ${ }^{141518}$

PAVMs are typically diagnosed by CCT or conventional pulmonary angiography. Usually, complications are due to paradoxical emboli that

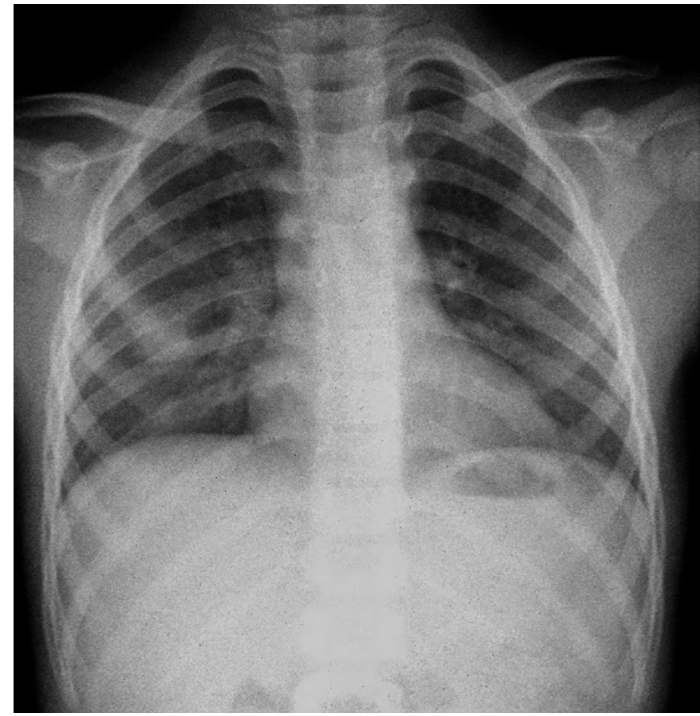

Figure 1 Thoracic radiography showing peribronchovascular thickening.

may cause ischaemic strokes, myocardial infarction, cerebral and peripheral abscesses, discitis and migraines. ${ }^{17}$ 19-23 Serious complications from PAVMs like massive haemoptysis and haemothorax are particularly more common in PAVMs $>3$ $\mathrm{mm} .{ }^{24-26}$ Risk-benefit analysis in adult patients are almost always in favour of treatment. ${ }^{27-29}$ However,

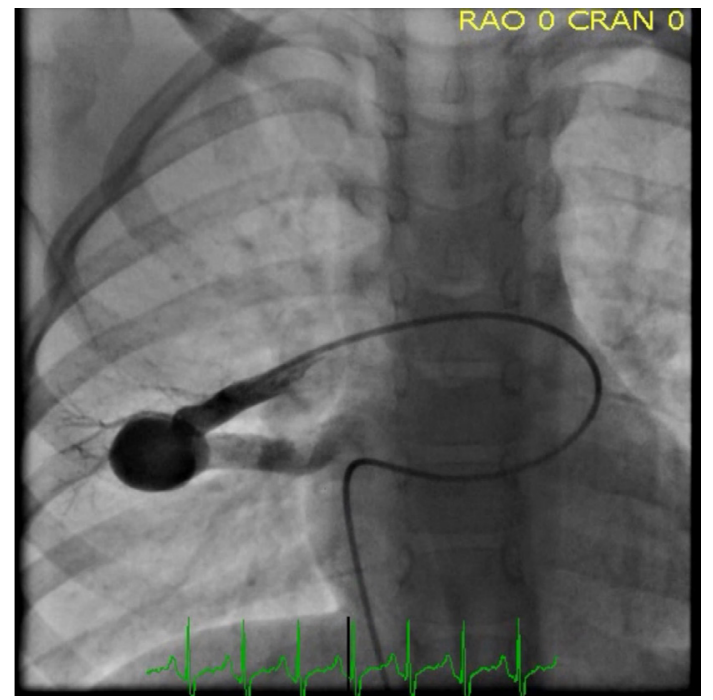

Figure 2 Pulmonary angiography revealing a large pulmonary arteriovenous malformation $(23 \times 19 \mathrm{~mm})$ on the right parahilar topography with afferent artery draining into the right upper pulmonary vein and efferent vessel draining into the left atrium. 
well-defined recommendations are still lacking for paediatric patients.

PAVM occlusion by embolisation is the gold standard of care. $^{172125}$ The selection of who to treat depends on factors including feeding artery diameter (FAD), PAVM-related symptoms and patient's ability to tolerate the procedure. ${ }^{14} 161730-34$ PAVMs that progressively enlarge (FAD $\geq 2-3 \mathrm{~mm}$ ) or become symptomatic should undergo evaluation for embolotherapy with pulmonary angiography. Surgery is an option for patients who fail repeated embolisation, for lesions suitable for intervention but not amenable for embolotherapy and for those who present with life-threatening acute haemorrhage from ruptured PAVM in a facility without access to embolotherapy. ${ }^{85-38}$ Due to paucity of data in children, more investigation is needed to state clear recommendations and uniformise therapeutic approach in this specific group.

\section{Learning points}

- Pulmonary arteriovenous malformations (PAVMs) are rare but an important consideration in the differential diagnosis of common pulmonary signs or symptoms, such as dyspnoea or hypoxaemia.

- PAVMs are typically diagnosed by computed chest tomography or conventional pulmonary angiography and their importance stems from the risks they pose (paradoxical embolic stroke, abscess, myocardial infarction and lifethreatening haemorrhage).

- Not all PAVMs require intervention. When indicated, most patients are treated with embolotherapy.

Contributors All authors have been personally and actively involved in substantial work leading to the paper and will take public responsibility for its content. MFC bibliographical search, study design, data collection, analysis and interpretation of data, and drafting of the article. OM—bibliographical search, study design, data collection and critical reviewing of the content of the article. RR - bibliographical search, study design, data collection and critical reviewing of the content of the article. ARA — bibliographical search, study design, data collection and critical reviewing of the content of the article.

Funding The authors have not declared a specific grant for this research from any funding agency in the public, commercial or not-for-profit sectors.

Competing interests None declared.

Patient consent for publication Obtained.

Provenance and peer review Not commissioned; externally peer reviewed.

ORCID iDs

Maria Filomena Cardosa http://orcid.org/0000-0001-9531-0471

Odete Mingas http://orcid.org/0000-0002-7977-4900

\section{REFERENCES}

1 Nakayama M, Nawa T, Chonan T, et al. Prevalence of pulmonary arteriovenous malformations as estimated by low-dose thoracic CT screening. Intern Med 2012;51:1677-81.

2 Cottin V, Dupuis-Girod S, Lesca G, et al. Pulmonary vascular manifestations of hereditary hemorrhagic telangiectasia (Rendu-Osler disease). Respiration 2007:74:361-78.

3 Guttmacher AE, Marchuk DA, White RI. Hereditary hemorrhagic telangiectasia. N Engl J Med 1995:333:918-24.

4 Shovlin CL. Hereditary haemorrhagic telangiectasia: pathophysiology, diagnosis and treatment. Blood Rev 2010;24:203-19.

5 Shovlin $\mathrm{CL}$, Jackson JE. Pulmonary arteriovenous malformations and other pulmonaryvascular abnormalities. In: Mason B, Murray N, eds. Murray and Nadel's textbook of respiratory medicine. 6th edn. Pennsylvania: Elsevier- Saunders, 2015.

6 Krowka MJ. Hepatopulmonary syndrome and Portopulmonary hypertension. Curr Treat Options Cardiovasc Med 2002:4:267-73.

7 Lange PA, Stoller JK. The hepatopulmonary syndrome. Ann Intern Med 1995;122:521.
8 Gossage JR, Kanj G. Pulmonary arteriovenous malformations. A state of the art review. Am J Respir Crit Care Med 1998;158:643.

9 Mathur M, Glenn WW. Long-Term evaluation of cava-pulmonary artery anastomosis. Surgery 1973;74:899.

10 Kim SJ, Bae EJ, Cho DJ, et al. Development of pulmonary arteriovenous fistulas after bidirectional cavopulmonary shunt. Ann Thorac Surg 2000;70:70.

11 Wong HH, Chan RP, Klatt R, et al. Idiopathic pulmonary arteriovenous malformations: clinical and imaging characteristics. Eur Respir J 2011:38:368-75.

12 Pugash RA. Pulmonary arteriovenous malformations: overview and transcatheter embolotherapy. Can Assoc Radiol J 2001;52:92.

13 Hales MR. Multiple small arteriovenous fistulae of the lungs. Am J Pathol 1956:32:927.

14 Cottin V, Chinet T, Lavolé A, et al. Pulmonary arteriovenous malformations in hereditary hemorrhagic telangiectasia: a series of 126 patients. Medicine 2007:86:1-17

15 Pollak JS, Saluja S, Thabet A, et al. Clinical and anatomic outcomes after embolotherapy of pulmonary arteriovenous malformations. J Vasc Interv Radiol 2006;17:35-45.

16 Mager JJ, Overtoom TTC, Blauw H, et al. Embolotherapy of pulmonary arteriovenous malformations: long-term results in 112 patients. J Vasc Interv Radiol 2004;15:451-6.

17 Shovlin $\mathrm{CL}$, Jackson JE, Bamford KB, et al. Primary determinants of ischaemic stroke/brain abscess risks are independent of severity of pulmonary arteriovenous malformations in hereditary haemorrhagic telangiectasia. Thorax 2008:63:259-66.

18 Angriman F, Ferreyro BL, Wainstein EJ, et al. Pulmonary arteriovenous malformations and embolic complications in patients with hereditary hemorrhagic telangiectasia. Arch Bronconeumol 2014;50:301.

19 Mowers KL, Sekarski L, White AJ, et al. Pulmonary arteriovenous malformations in children with hereditary hemorrhagic telangiectasia: a longitudinal study. Pulm Circ 2018:8:204589401878669.

20 Shovlin CL, Chamali B, Santhirapala V, et al. Ischaemic strokes in patients with pulmonary arteriovenous malformations and hereditary hemorrhagic telangiectasia: associations with iron deficiency and platelets. PLoS One 2014;9:e88812.

21 Post MC, Thijs V, Schonewille WJ, et al. Embolization of pulmonary arteriovenous malformations and decrease in prevalence of migraine. Neurology 2006;66:202-5.

22 Elphick A, Shovlin CL. Relationships between epistaxis, migraines, and triggers in hereditary hemorrhagic telangiectasia. Laryngoscope 2014;124:1521-8.

23 Ratjen A, Au J, Carpenter S, et al. Growth of pulmonary arteriovenous malformations in pediatric patients with hereditary hemorrhagic telangiectasia. J Pediatr 2019;208:279-81

24 Cottin V, Gamondes D, Schuller A, et al. Near-Fatal haemorrhage from pulmonary arteriovenous malformation in HHT with increased cardiac output. Eur Respir Rev 2009;18:190-2.

25 Shovlin CL, Sodhi V, McCarthy A, et al. Estimates of maternal risks of pregnancy for women with hereditary haemorrhagic telangiectasia (Osler-Weber-Rendu syndrome): suggested approach for obstetric services. BJOG 2008;115:1108-15.

26 Majumdar S, McWilliams JP. Approach to pulmonary arteriovenous malformations: a comprehensive update. J Clin Med 1927;2020:9.

27 Gupta S, Faughnan ME, Bayoumi AM. Embolization for pulmonary arteriovenous malformation in hereditary hemorrhagic telangiectasia: a decision analysis. Chest 2009;136:849-58

28 Hsu CC, Kwan GN, Thompson SA. Embolisation for pulmonary arteriovenous malformation. Cochrane Database Syst Rev 2012;8:CD008017

29 Donaldson JW, McKeever TM, Hall IP, et al. Complications and mortality in hereditary hemorrhagic telangiectasia: a population-based study. Neurology 2015;84:1886-93.

30 White RI, Lynch-Nyhan A, Terry P, et al. Pulmonary arteriovenous malformations: techniques and long-term outcome of embolotherapy. Radiology 1988;169:663-9.

31 Trerotola SO, Pyeritz RE. PAVM embolization: an update. AJR Am J Roentgenol 2010;195:837-45.

32 Faughnan ME, Palda VA, Garcia-Tsao G, et al. International guidelines for the diagnosis and management of hereditary haemorrhagic telangiectasia. J Med Genet 2011:48:73-87.

33 Chick JFB, Reddy SN, Pyeritz RE, et al. A survey of pulmonary arteriovenous malformation screening, management, and follow-up in hereditary hemorrhagic telangiectasia centers of excellence. Cardiovasc Intervent Radiol 2017;40:1003-9.

34 Lee DW, White RI, Egglin TK, et al. Embolotherapy of large pulmonary arteriovenous malformations: long-term results. Ann Thorac Surg 1997:64:930-40.

35 Shovlin CL. Pulmonary arteriovenous malformations. Am J Respir Crit Care Med 2014:190:1217-28.

36 Shovlin CL, Condliffe R, Donaldson JW, et al. British thoracic Society clinical statement on pulmonary arteriovenous malformations. Thorax 2017;72:1154-63.

37 Puskas JD, Allen MS, Moncure AC, et al. Pulmonary arteriovenous malformations: therapeutic options. Ann Thorac Surg 1993:56:253-8.

38 Pierucci P, Murphy J, Henderson KJ, et al. New definition and natural history of patients with diffuse pulmonary arteriovenous malformations: twenty-seven-year experience. Chest 2008;133:653-61. 
Copyright 2021 BMJ Publishing Group. All rights reserved. For permission to reuse any of this content visit https://www.bmj.com/company/products-services/rights-and-licensing/permissions/

BMJ Case Report Fellows may re-use this article for personal use and teaching without any further permission.

Become a Fellow of BMJ Case Reports today and you can:

- Submit as many cases as you like

- Enjoy fast sympathetic peer review and rapid publication of accepted articles

Access all the published articles

Re-use any of the published material for personal use and teaching without further permission

Customer Service

If you have any further queries about your subscription, please contact our customer services team on +44 (0) 2071111105 or via email at support@bmj.com.

Visit casereports.bmj.com for more articles like this and to become a Fellow 